\title{
Moving Towards Legitimate Participation. A Venezuelan Girl Learning English in an lowa City Elementary School
}

\author{
Hacia la participación legítima. El proceso de aprendizaje de inglés de una niña venezolana \\ en una escuela primaria de lowa City
}

\section{Para uma legítima participação. 0 processo de uma menina venezuelana e sua aprendizagem do Inglês numa escola primária em lowa City}

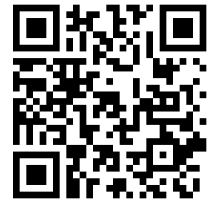

\author{
José Miguel Plata-Ramírez ${ }^{1}$ \\ Universidad de los Andes \\ Mérida, Venezuela \\ jomiguel150@hotmail.com
}

http://orcid.org/0000-0003-3125-1868

Recibido 19 de abril de 2016 • Corregido 24 de mayo de 2017 • Aceptado 31 de julio de 2017

Received 19 de abril de 2016 • Revised 24 de mayo de 2017 • Accepted 31 de julio de 2017

Recebido 19 de abril de 2016 • Revisado 24 de mayo de 2017 • Aprovado 31 de julio de 2017

\begin{abstract}
This qualitative case study seeks to understand and describe, in depth, the different learning processes in which a nine-year old, Venezuelan girl (Victoria) engaged to reaffirm her identity as a language learner and become a legitimate member of a community of practice during the first six months in an lowa City Elementary School. Data collection included observations in class and at home, field notes, interviews, oral and written artifacts and e-mails. Analysis was made through a constant comparison of the data to reflect on the potential categorizations of the artifacts considering mainly two theoretical constructs:"legitimate peripheral participation" (Lave \&Wenger, 1991) and "collaborative relations of power" (Cummins, 1996). Results suggest that students engage more actively in activities, which are designed to construct meaning through social participation. Legitimate participation in school activities helped Victoria improve her English language ability and reaffirm her identity. The speed with which she learned English at school is mainly due to the solid community of practice she had the fortune to participate in and Mrs. Brown's mediation. The more she interacted, the better she performed; and the better she performed, the more she interacted. This research offers alternative ways to understand Victoria's experience as a language learner, the complexity of a second language learning process, and the fundamental role teachers need to perform to mediate in the students' learning
\end{abstract}

\footnotetext{
${ }^{1} \mathrm{He}$ is an Associate Professor and Researcher at the Foreign Language Research Center of the Universidad de Los Andes, Mérida-Venezuela since 1997. He has a Bachelor in Literature and a Masters in Linguistics from the Universidad de Los Andes, Venezuela and holds a Ph.D. in Teaching and Learning from the University of lowa, USA. He has several academic publications (articles and chapters) in the areas of teaching of reading and writing of English as a foreign language. Some of his short stories have been published in different fiction anthologies from the Writers Association in Mérida-Venezuela. He was awarded first place in the Short Story International Contest "Latin Heritage Foundation 2011" with his short story entitled: Punto Final (Full Stop). His novel, The North is a Chimera, was published in 2013.
} 
doi: http://dx.doi.org/10.15359/ree.21-3.1

URL: http://www.una.ac.cr/educare

CORREO: educare@una.cr

to reaffirm their identities. This study represents an exemplary reflection of what we, as classroom teachers, SL/foreign language teachers, should do in our classrooms if we really want to offer students real opportunities to learn the language and help them reaffirm their identity as language learners.

Keywords: Legitimate peripheral participation; relations of power; learning; identity; newcomer.

Resumen: Este estudio de caso cualitativo busca comprender y describir en detalle los diferentes procesos de aprendizaje en los que una niña venezolana de nueve años (Victoria) participó para reafirmar su identidad como aprendiz de lengua y convertirse en miembro legítima de una comunidad de practicantes durante los primeros seis meses en una escuela primaria de lowa City. La recolección de datos incluyó observaciones en clase y en casa, notas de campo, entrevistas, producciones orales y escritas y correos electrónicos. El análisis se realizó mediante una comparación constante de la información recopilada para reflexionar sobre las posibles categorizaciones de los datos considerando principalmente dos constructos teóricos: "la participación periférica legítima” (Lave \& Wenger, 1991) y "relaciones colaborativas de poder" (Cummins, 1996). Los resultados sugieren que el estudiantado participa más activamente en las actividades diseñadas para construir significado a través de la participación social. La legítima participación en las actividades escolares ayudó a Victoria a mejorar su habilidad en el idioma inglés y a reafirmar su identidad. La rapidez con que aprendió inglés en la escuela se debe, principalmente, a la sólida comunidad de practicantes en la que tuvo la fortuna de participar y la mediación de la Sra. Brown. Cuanto más interactuaba, mejor se desempeñaba y cuanto mejor se desempeñaba, más interactuaba. Esta investigación ofrece formas alternativas de entender la experiencia de Victoria como aprendiente de lengua, la complejidad de un proceso de aprendizaje de segunda lengua y el papel fundamental que el profesorado debe desempeñar para mediar en el aprendizaje estudiantil para reafirmar sus identidades. Este estudio representa un claro ejemplo de lo que deberíamos hacer en nuestras aulas, como maestros y maestras de aula / docentes de lenguas extranjeras, si realmente queremos ofrecerle al estudiantado oportunidades reales de aprender lengua y ayudarle a reafirmar su identidad como aprendices.

Palabras claves: Participación periférica legítima; relaciones de poder; aprendizaje; identidad; recién llegado.

Resumo: Este estudo qualitativo de caso busca compreender e descrever em detalhe os diferentes processos de aprendizagem nos quais uma menina venezuelana de nove anos participou para reafirmar a sua identidade como aprendiz de um idioma e tornar-se membro legítimo de uma comunidade de praticantes durante os primeiros seis meses numa escola primária em lowa City. A coleta de dados incluiu observações na sala de aula e na sua casa, notas de campo, entrevistas, produções orais e escritas e correios eletrônicos. A análise foi realizada utilizando uma comparação constante da informação encontrada para refletir sobre possíveis categorizações dos dados, considerando, principalmente, duas construções teóricas: "participação periférica legítima" (Lave \& Wenger, 1991) e "relações colaborativas de poder" (Cummins, 1996). Os resultados sugerem que os estudantes são más ativos nas atividades destinadas a construir significado através da participação social. A legítima participação nas atividades escolares ajudou Victoria a melhorar sua habilidade no idioma Inglês e reafirmar a sua identidade. A rapidez com que aprendeu Inglês na escola, foi devido principalmente à uma boa comunidade de praticantes na que teve a sorte de participar e a mediação da Sra. Brown. Quanto mais interagia, melhor se desempenhava e quanto melhor se desempenhava, mais interagia. Esta pesquisa fornece alternativas 


\begin{abstract}
para compreender a experiência de Victoria como uma estudante de idioma, a complexidade de um processo de aprendizagem de uma segunda língua e o papel fundamental que desempenham os professores na mediação da aprendizagem estudantil para reafirmar suas identidades. Este estudo representa um claro exemplo do que deveríamos fazer em nossas salas de aula, como professores e professoras de um idioma estrangeiro, se realmente queremos oferecer aos estudantes oportunidades reais para aprender a língua e ajudar a reafirmar a sua identidade como aprendizes.
\end{abstract}

Palavras chaves: Participação periférica legítima; relações de poder; aprendizagem; identidade; recém chegado.

\title{
Introduction
}

Victoria (Pseudonym) is a nine-year-old Venezuelan girl who moved, with her family, to the U.S. to live for 5 years. After fifteen months living and learning the American English language and culture, Victoria (my daughter) feels comfortable and usually prefers to speak English to me. In contrast, as a language learner and as an English language teacher in Venezuela, I have been learning English for more than twenty years and still, Victoria feels the need to code switch from English to Spanish in order to help me understand the kind of words that are not usually taught in a language classroom. There are many factors that converge in this phenomenon we need to analyze in order to fully understand Victoria' rich linguistic repertoire.

As a newcomer to a linguistic community in the U.S., Victoria engaged in multiple activities within that community of practice as a second language learner. In a second language learning context such as the U.S. "students will hear English when they leave the classroom whether they are on the play-ground, in a store, or in front of the television" (Freeman \& Freeman, 1998, p. 4).

This means that there are many variables such as age, gender, social status which play pivotal roles in a second language learning process; however, in this paper special attention will be paid to the kind of language Victoria has been exposed to as a newcomer, the kind of classroom activities her teacher planned, the degree of learners' participation in those activities, the kinds of language-related games she engaged with peers, her family support to learn the new language and her attitude as a learner, among others.

My main purpose in this paper is to reflect on Victoria's first academic experience as a newcomer in an U.S. elementary classroom and make sense of how her interactions with her peers and her teacher shaped and reaffirmed her identity as a language learner as she started moving from the peripherality towards full participation. In spite of the many reported pitfalls some Latino children face in the U.S. schooling, it is my desire to narrow my guesses about the different factors that may have contributed to Victoria's learning success using two particular theoretical constructs: "legitimate peripheral participation" (Lave \& Wenger, 1991) and "collaborative relations of power" (Cummins, 1996). These two theoretical constructs are the means by which I understand Victoria's construction of identity as a biliterate student and 
doi: http://dx.doi.org/10.15359/ree.21-3.1

URL: http://www.una.ac.cr/educare

CORREO: educare@una.cr

as a member of a new community. Furthermore, I will consider the fundamental work in the language learning and learning development from Halliday's (1977), Goodman's (2003) and Vygotsky's (1978) to strengthen and nurture my analysis.

\section{Theoretical Framework}

\section{Legitimate Peripheral Participation (LPP)}

Beyond seeing learning as a matter of internalization, Lave and Wenger (1991) suggest the idea of constructing learning by participating in a community of practice in which newcomers engage in multiple activities to become full participants. By participating, getting familiar with the rules, habits and activities of the new community and interacting with old timers, new comers move from the peripherality towards a full participation in such a community. In order to explain this definition, Lave and Wenger (1991) state that the participation of members in those relationships is "legitimate" since members have a sense of belonging and "peripheral" since newcomers go from low to high in their participation. These authors define "communities of practice as "a set of relations among persons, activity and world, over time and in relation with other tangential and overlapping communities of practice" (Lave \& Wenger, 1991, p. 98).

\section{Collaborative Relations of Power (CRP)}

Students' attitudes toward language learning and participation in the new culture will strongly depend on the awareness teachers have to empower them and help them affirm their identities as language learners (Cummins, 1996). According to Cummins (1996) affirmation of identity, which is not an uncritical process, "refers to the establishment of respect and trust between educators and students that is crucial to reflect critically on their experiences and beliefs" (p.4) and this can be encouraged through "collaborative relations of power". Collaborative relations of power suggest that power is not fixed but rather can be generated in interpersonal and intergroup relations. That is to say, participants in a relationship are empowered through their collaboration and understanding so that each one of them "is more affirmed in her/his identity" (p. 15). Teachers should listen carefully and learn from their students' perspectives and students need to respect others and get benefits from what they experience.

In this respect, Foucault (1990) agrees in that it is almost impossible to imagine a situation in which power is not present or cannot be generated. He says that "power is everywhere, not because it embraces everything, but because it comes from everywhere" (p. 93). According to Foucault (1995) power then should not be seen as a possession by particular individuals or groups like teachers but as a complex and diffused field of relationships in which everybody is engaged. The distribution of power in relationships between teachers and students is of 
paramount importance. As a culturally diverse student, Victoria experienced how her teacher's mediation helped her feel proud of whom she was in her new community.

As I said before, these theoretical constructs are framed within sociocultural theories such as the works of Halliday (1977), Vygotsky (1978) and Goodman (2003). Halliday (1977) sees language as a social semiotic and proposes that learning language is learning how to mean. Children learn languages through the languages themselves. Vygostky (1978) introduces the term "mediation" in which the teacher plays the role of mediator by supporting the learning, not controlling it. He also contributes the concept of Zone of Proximal Development which explains how learners develop skills with the help of a more capable peer. Goodman (2003) states that two major forces (invention and convention) interact in the language development of a child and that learning language goes from whole to parts. Together, these sociocultural theories help us understand the whole picture of Victoria's language development and also allow us contextualize the theoretical constructs I have already described.

\section{Literature Review}

A great number of studies have referred to the complex process of developing the second language (L2) itself and the fundamental roles of parents to foster literacy in those second languages (Bissex, 1980; Hakuta, 1976; Martens, 1996; Schwarzer, 2001, 2007; Wei \& Zhou, 2003). Some studies have focused on discussing the Latino's learners standpoint about language and schooling in the U.S., in which their complex reality in bilingual and multidialectal speech patterns are usually misunderstood and devalued (Bayley \& Schecter, 2005; Bhimji, 2005; Ek, 2005; Zentella, 2005). These studies have discussed fundamental aspects such as the home language maintenance, culture, identity, immigration and misconceptions about Latino people living and learning in the U.S. Research suggests that teachers need to foster students' home languages and their "Funds of Knowledge" to help them become biliterate (Cummins, 1996; Schwarzer, 2001; González, Moll \& Amanti, 2005). Some other studies have highlighted the negotiation and reaffirmation of identity process through collaborative relations of power such as (Morita, 2004; Cummins, 1996) and some others have emphasized the development of second language acquisition and language identity through legitimate participation in communities of practice and the adjustment to new cultures (Back, 2011; González-Howard \& McNeill, 2016; Han, 2009; Nordstrom, 2015). Bacon (2002) states that language proficiency develops when learners understand societal and academic rules, which in turn, allow them function within the culture.

It is worth noting here that some research have also evidenced that such reaffirmation of identity and full participation in communities are not always achieved due to some constrains that prevent learners from participation. For instance, Toohey (1998), in her study with preschoolers found that the practices in certain communities "appear in effect to prevent the increasing empowerment and active participation of some of those defined as L2 learners" and that some students "become 
doi: http://dx.doi.org/10.15359/ree.21-3.1

URL: http://www.una.ac.cr/educare

CORREO: educare@una.cr

defined as deficient and are thus systematically excluded from just those practices in which they might otherwise appropriate identities and practices of growing competence and expertise" (p. 61). Zentella (2005) claims that negative attitudes toward the ways Latinos speak English have been perpetuated in the U.S. and this has negatively affected their performance at schools and identity. Likewise, Norton (2001) examined the relationship between non-participation and the imagined communities of two ESL learners in Canada. In her study, she concludes that "language learner's non-participation in a second language class may result from a disjuncture between the learner's imagined community and the teacher's curriculum goal" (p. 170). In this respect, Lave and Wenger (1991) recognize that particular social arrangements of a specific community may prevent of facilitating participations of its members and Wenger (1998), in developing the notions of participation and non-participation, states that learners'identities are shaped by the two. He states that marginality is a way of preventing full participation in a community. Cummins (1996) states that relations between students and educators are never neutral. They can reinforce the status quo of coercive relations of power to disempowering students, or they can encourage a collaborative relation of power to help students develop their potential.

These studies help us understand the fundamental role teachers play to foster language development at school, the pivotal role parents play in their children's learning, the constrains and devaluing identity practices and the complexity and intricate process of participation and non-participation within a community of practice during second language learning. It is my desire that the present study will contribute to the existing literature by presenting an experience which describes the transactions that occurred between the teacher, in an attempt to create opportunities to reaffirm the student' identity as a language learner, and the learner, in an attempt to become a legitimate participant in a new community of practice.

\section{Problem and research questions}

Victoria was a mainstreamer in a traditional classroom in Venezuela and moved to the U.S. with the challenge of becoming a mainstreamer in the new community. With no English at all before coming to the U.S., Victoria was placed in Mrs. Brown's fourth grade classroom, which gave her opportunities to learn and develop her language skills in English at an accelerated rate. In only a matter of months, Victoria had constructed sufficient knowledge in the new language to code switch and talked to me in Spanish when she thought I did not understand what she had said.

Although bilingual development research has documented that children develop second languages at a faster rate than adults do (Cummins, 1996; Hakuta, 1986; White, 2003), contemporary sociocultural literature regarding the processes of learning literacy such as "legitimate peripheral participation"(Lave \&Wenger, 1991) and"collaborative relations of power" (Cummins, 1996) offer alternative ways to perceive and understand how bilingual children participate in activities to construct their own learning when they perform different roles. Though

6

José Miguel Plata-Ramírez

Los artículos de la Revista Electrónica Educare del Centro de Investigación y Docencia en Educación de la Universidad Nacional, Costa Rica, se comparten bajo términos de la Licencia Creative Commons: Reconocimiento, No Comercial, Sin Obra Derivada 3.0 Costa Rica. Las autorizaciones adicionales a las aquí delimitadas se pueden obtener en el correo: educare@una.cr 
some researches have also shown that not all newcomers succeed in becoming legitimate participants in the new community (Norton, 2001; Toohey, 1998), Victoria's experience stands as one fortunate case. Considering these important issues on learning literacy, I conducted this particular qualitative case study in order to understand:

- What kinds of activities did Victoria experience, which made her move towards participation and become a legitimate member of her new community of practice?

- How is Victoria portrayed as a legitimate participant in the new community?

- How did Mrs. Brown's mediation help Victoria reaffirm her identity as a language learner?

\section{The Study}

This study is a qualitative case study, which seeks to reflect, understand and describe in depth the different learning processes in which a nine-year old, Venezuelan girl engaged to reaffirm her identity as a language learner and become a legitimate member of a community of practice during the first six months in the U.S. Merriam (1998) states that the case study can be defined considering its special features: particularistic, descriptive and heuristic. Hence, a case study considering Victoria's L2 learning process offers an intensive and holistic description and analysis of this single educational real-life context phenomenon and contributes to a general understanding of it.

\section{The Participants}

In this section I want to portray the three major participants in the study with the purpose of offering relevant background information, which is fundamental to understand Victoria's language development. The three participants are:Victoria, her teacher Mrs. Brown (pseudonym) and me (father and researcher).

\section{- Victoria}

At the time of data collection, Victoria was nine years old. She moved to the United States with her mother, her then thirteen-year old sister and me. Our plan was to live and study in lowa City, USA, for 5 years. Victoria had never been exposed to the English language in her home country before coming to the United States. She was a successful mainstream third grader in a Venezuelan Catholic-oriented elementary school where she was used to typical Venezuelan school activities. Her classroom in Venezuela was mainly based on a transmission model and classes were teacher-centered. She was good at memorizing, well behaved, disciplined and with good academic results. The language-related activities in Victoria's former class followed what Cazden (2001) called the three-part pattern (I.R.E.), that is to say, the teacher initiates, students respond, and the teacher evaluates. As a consequence, Victoria was used to follow instructions 
doi: http://dx.doi.org/10.15359/ree.21-3.1

URL: http://www.una.ac.cr/educare

CORREO: educare@una.cr

passively, copy from the blackboard without interacting with her peers and respond to the teacher when she was asked. Learning did occur in those classes but children were given few opportunities to actively participate. According to Smith's classical theory of learning, people always learn in positive or negative ways (Smith, 1998). Victoria had learned to not participate very often in class. It is interesting though that Victoria, within the Venezuelan community of practice, was a legitimate participant who usually stayed closer to the periphery than to the center. Power in that context was not equally distributed and hence Victoria was kept closer to the periphery than from participating more fully.

\section{- Mrs. Brown}

By the time of data collection, Mrs. Brown had fourteen years of teaching experience. She holds a B.A. in Elementary Education with emphasis on multicultural education and an M.A. in Elementary Education with emphasis on curriculum design from the University of lowa. She has worked in the same school since its opening. She is married to an American high-school Language Arts teacher who reads and understands some Spanish and who helps Mrs. Brown understand some of her students' writing in Spanish. As a Japanese-American, Mrs. Brown is well acquainted with cultural differences and how they influence learners. She is quite conscious that her background shaped her perceptions about her culturally diverse students.

As a teacher in her school, she has participated in several in-services when teachers' perceptions of students who come from backgrounds that differ from their own "mainstream" culture have been addressed. These experiences added to her awareness of the needs of students from other countries who enter her classroom for the first time. She makes an effort to provide both written and visual cues for important signs in her classroom, including lunch menu items, bathroom passes, schedules, etc. In general, she considers students' different learning styles and the need to differentiate her instruction for all students. She makes sure that much of the learning is "hands on" and relevant to all of her students.

\section{- My role as a parent-researcher}

My role as a parent and researcher provided me the opportunity not only to observe Victoria at school but to observe, interact and reflect with her at home about her experiences during class time and her development of English. There exists a long tradition in the early literacy literature in which parents are researchers about their children's language development (see Bissex, 1980; Martens, 1996; Schwarzer, 2001; Wei \& Zhou, 2003). Assuming such a role in the language learning process of our own children offers many advantages, such as closeness to the participant and the permanent possibility to systematically observe, interact and reflect with the child, something that a non-relative could not access. However, research by parents also 
brings about negative limitations that could obscure the results of the whole study, such as the misinterpretation of facts due to the close child-parent relationship, that is to say the researcher's bias. All parents want their children to do the best and this is a fundamental factor to consider when analyzing the data in order to offer a sound picture of the process. In my particular case, in order to avoid possible misinterpretations or misunderstandings due to my filial relationship with Victoria and with the clear intention to empower the validity of the study, I regularly shared and discussed my insights with Mrs. Brown and Victoria in order to contrast their points of views with mine. This process is what Merriam (1998) calls a "member check" strategy.

\section{Data collection}

This research mainly involves the first six months of classes within an lowa City school, which lasted from August to November. Data was collected using different ethnographic methods, such as participant observations and semi-structured interviews with her teacher since they allow an in-depth scrutinizing of the phenomenon being studied. The data collected also included: Victoria's written and oral artifacts, and home conversations between Victoria and me to reflect about her experiences in class. I also collected some additional data by emailing Mrs. Brown and using part of her written responses to portray her as a participant-teacher in this study.

\section{Observations, Field notes, Interviews, Oral and written artifacts}

I visited Victoria's school four times, for ninety minutes each visit. During those visits, I observed her and took field notes of each activity occurring in the class and expanded them at home. Moreover, during those months I also observed and interacted with Victoria at home and audio-taped and transcribed our interactions, her reading-aloud and personal reflections about her experiences at the new school. Some of her written artifacts were collected as evidence of her progress. I also audio-taped and transcribed two interviews with Victoria's teacher which gave me an opportunity to have a more complete understanding from Mrs. Brown's insights of what I had observed in her classroom.

\section{- Victoria's new school}

Victoria's new school in lowa City bases its education on community building. This implies four principles that influence and direct the teaching and learning process. These four principles are as follows: a strong community of learners, a coherent and seamless curriculum, a strong character program, and a climate for learning. As a result, these four basic principles strengthen a community sense among children and teachers in this school. Particularly relevant to this study, the principal as well as all the teachers are aware about culturally diverse students and participate in in-service workshops to discuss how diverse cultures influence the way students learn. 
doi: http://dx.doi.org/10.15359/ree.21-3.1

URL: http://www.una.ac.cr/educare

CORREO: educare@una.cr

As a new fourth grader, Victoria joined "Team Three" under the guidance of Mrs. Brown. This class was made up of 24 third and fourth graders sharing a comfortable environment. Children sat at their desks, which were organized in six small groups of four students each. So students were not rigidly sitting at their desks like in Victoria's former school but had the opportunity to share and interact on a daily basis. In the classroom, there was plenty of written material everywhere; signs on the walls regarding the goals for the year, a lot of books available for students, and a board with the schedule of students' daily responsibilities, lunch menu items, bathroom passes, and schedules. This amount of written material allowed Victoria to gain familiarity with the English language from the very first day. As a native Spanish speaker, Victoria was also placed in an English Language Learning (ELL) class intended for non-English speaking students in the school. Victoria attended this class everyday for one hour under the supervision of Miss Jensen (pseudonym). This class was made up of five other students from Korea and China.

\section{Analysis}

To start the analysis for this study I considered all the different pieces I had collected from my observations, field notes, interviews, e-mails, home interactions, Victoria's transcripts and written artifacts. My intention was to identify themes related to my research questions. To this respect, Chiseri-Strater and Sunstein (2006) state that "interpretations and analysis come naturally, since triangulation requires that you scrutinize, match and connect your data closely with your research question"(p. 144). Considering this, I focused on my research questions and first created two major categories with are closely related to the research questions: a) Legitimate participation and b) Reaffirming identity. In the first category (Legitimate participation) I grouped all the data related to three key concepts regarding legitimate peripheral participation: "newcomer", "acceptance of language approximation" and "playing different roles". In the second category (Reaffirming identity) I grouped all data related to "use of native language", "interpersonal collaboration" and "power distribution". Glesne (2006) suggests that in data analysis there is a need to code, categorize and theme-search through your data to make connections which in turn gives you the chance to reflect upon what you have learned and make new connections.

Next, I examined closely the written and oral artifacts Victoria created in our home interactions. I recognized some interesting issues regarding language development so I created a third category under the name "Reflecting on Learning" in which I grouped all data related to "learning reflection" and "language development". Manipulating the data back and forth in order to reflect on the potential categorizations of the artifacts, assign categories, move samples from one category to another, and establish connections among samples helped me deeply understand not only the complex process of analysis but, more importantly, the theoretical constructs I was dealing with. The categories became more distinct as I read all the transcripts and field notes, listened to the audio-taped interviews, matched the data which fit under those categories, and reflected upon my beliefs and what I have observed. 


\section{Victoria's critical experience in the new community of practice}

In the following two categories:"Moving towards legitimate participation", and"Reaffirming identity as a language learner"I present examples, identified during data analysis, which may illustrate the theoretical constructs of "legitimate peripheral participation" and "collaborative relations of power'"' It is worth noting here that many examples overlap categories due to the intrinsically convergent points such as "engagement", "participation", "power distribution" and "interaction". In addition, I present a third category under the name of "Reflecting on learning" in which I share and comment Victoria's reflections on her own learning. Samples for this category, which include written pieces and transcriptions from our oral conversations, were mainly taken from our home interactions in which I usually asked her to show her progress.

\section{Moving towards legitimate participation}

In Victoria's classroom, students interacted with their teacher and peers, and also were free to go around the classroom to accomplish different tasks such as watering the plants, publishing the students' daily classroom responsibilities on a board, doing collaborative reading, among others. These ways of participation and the interactive activities were new to Victoria who was used to more passive learning and direct instruction. So, Victoria's new experience at school was twofold since it meant she was learning different teaching modes and class activities, at the same time, she was constructing literacy in a new language by interacting with her peers and engaging in those activities.

Lave and Wenger (1991) state that "in addition to learning from models, learning takes place through interaction" (p. 83). Victoria's learning began immediately from her first day as she engaged with others in a community that invited her to participate as a genuine member, by performing given roles, by reflecting about what she learned and by understanding herself as a language learner. From this viewpoint, learning refers to the increasing participation of the whole person in the community of practice by performing different roles. The following example from my field notes shows how Victoria, as a newcomer, was engaged as a legitimate participant in her new community of practice. Notice how Victoria moved from a silent participant role (as an observer-doer) to a more talkative participant role (as a speaker-doer):

\section{Sample 1: The sound research project:}

Victoria was involved in a four-student group research project trying to discover the different means by which sound travels. They were asked to go out of the classroom, to the school corridor, and try different means such as the floor, the walls, and the students' lockers to collect information of how sounds travel. They were given a piece of wood and a sound fork as tools to collect the information. While Victoria made the fork sound and put it on the floor surface, two students were lying with their ears on the floor trying to listen and to prove if 
doi: http://dx.doi.org/10.15359/ree.21-3.1

URL: http://www.una.ac.cr/educare

CORREO: educare@una.cr

sound travelled across. The other child served as a communicator bridge between Victoria and the sound-catchers. The child in the communicator bridge role, asked questions such as: "did you guys hear that?" And reported to Victoria: "Yes, they did. Why don't you repeat that sound?" While asking this, the boy made gestures with his hands encouraging Victoria to make the fork sound again. They interacted with one another. Children moved to different places and changed roles to sound the fork, to listen carefully and to act as messengers. At first, Victoria seemed to observe and model what the other kids did. She spent half of the activity time playing the sound maker role. Then she started performing the other roles in spite of her limited oral skills in English in that cooperative learning experience. As a messenger, Victoria asked the other kids "You hear?", and as a sound catcher she used the words "high" or "low" to describe the intensity of the sound. Field notes taken in October $23^{\text {rd }}$

During the sound project the students negotiated with each other trying to agree about how to describe the quality of the sounds they heard. When they talked to Victoria, they spoke slowly and gestured with their hands in order to help her understand. Although Victoria did not talk much, she nodded her head and used the words "high" or 'low" to describe the intensity of the sound or asked the question:"you hear?" when she acted as the messenger. The other group members seemed to have an intuitive knowledge about how to engage Victoria in the activity. They repeated the questions, gestured and rephrased what she said. Victoria was developing her personal invention and adapting it to the social convention (Goodman, 2003). They never corrected her and her words "high", "low" and "you hear" were accepted and rephrased to adapt them according to the conventional rules.

These actions of the part of her peers served to mediate her participation by not correcting her but by rephrasing parts of her speech. Lave and Wenger (1991) refer to this characteristic when they describe the Alcoholic Anonymous modus operandis in which old members do not correct newcomers but help them by ignoring their inappropriate words and rephrasing and expanding the newcomers' ideas. From the periphery, Victoria was not kept from participating but started to gradually participate in different transactions with the other children to learn the code of that community of practice. She initially performed the role of the sound maker and after a while she became sufficiently comfortable to perform the other roles. Her previous experience as a class member in these kinds of activities and her understanding of the new tasks were in constant interaction as Lave and Wenger (1991) suggest.

Oral language was not a barrier in that group since the activity they were engaged in was fully contextualized and provided the perfect scaffold to develop language. These kinds of complex relationships are what Lave and Wenger (1991) entail in a theory of social practice. As they state "a theory of social practice emphasizes the relational interdependency of agent and world, activity, meaning, cognition, learning and knowing" (p. 50). She not only learned some language by participating in the activity and interacting with the other kids, but most importantly, 
she was constructing literacy about the physics of sounds. Victoria was transforming not only her behavior to do things but her identity as a learner, as a language user, as a friend, as a member of that particular group, and as a contributor toward the overall Team 3 goal. At the same time, she started moving from the periphery towards a more frequent participation, which implies a power distribution among the kids and their complex interdependent relationships. Victoria was given the power to participate by "doing" and say what she knew to contribute in the overall project.

\section{Reaffirming identity as a language learner}

Since the beginning of classes, Victoria participated in different activities, which helped her construct learning and affirm her own identity as a language learner. Although Victoria's teacher did not speak Spanish, she showed her awareness of cultural differences since she was always supportive and respectful with Victoria's performance in class. She spoke slowly to her and rephrased ideas with a natural smiling face. She used gestures with her hands and body, so that Victoria could understand and feel comfortable. Mrs. Brown was helping Victoria to affirm her identity by understanding and encouraging her to use her native language and by giving her the power to "do it".

Cummins (1996) states that "affirmation of identity refers to the establishment of respect and trust between educators and students that is crucial to reflect critically on their experiences and beliefs" (p. 4). This affirmation of identity is possible through "collaborative relations of power" in which students and teachers are empowered to value and respect the others' differences. Likewise, Cazden (2001) strongly emphasizes the need for cultural difference awareness within a classroom for students' better performance in contrast with cultural deficit. The following excerpt from my field notes is an example of a classroom interaction between Victoria and Mrs. Brown in an attempt of Mrs. Brown to encourage her to perform the task with the help of a peer:

\section{Sample 2: Collaborative reading}

Mrs. Brown asked the children to get ready with their books. The children opened their desks, got their books and got ready to read. She looked at Victoria and told her "if you want you can read some of those" pointing with her finger to a small bookcase in the classroom. Victoria looked at her with her eyes wide opened and said nothing. Mrs. Brown walked and grabbed a book (Trick or Treat) from the bookcase and opened it. With a hand movement she invited Victoria to get close to her. Victoria whispered (I could not hear). Mrs. Brown opened the book and told her "you can try this" pointing with her finger to the content of the book pretending she was reading. Victoria nodded her head and grabbed the book. Mrs. Brown helped Victoria to ask a question in English to a girl (Molly) to help her with the reading. Mrs. Brown made Victoria repeat: "May I read a book to you?. Molly joined Victoria and they both sat on the rug and Victoria started to read aloud and Molly helped her pronounce some words and sometimes led the reading with a louder voice... Field notes taken in October $23^{\text {rd }}$ 
doi: http://dx.doi.org/10.15359/ree.21-3.1

URL: http://www.una.ac.cr/educare

CORREO: educare@una.cr

Mrs. Brown commented in an interview that she perceives all of her students as having different learning styles. She is aware of the need to make sure she does not only "talk" to some of her students, but to all, especially those who are just learning English. She makes sure that all the students can understand and participate in her activities and makes sure that directions are clear with gestures, pictures and modeling. In this case, Mrs. Brown used a lot of gestures to help Victoria understand her task. She empowered Victoria to try a new reading but at the same time Mrs. Brown conveyed to her that she was a valuable member of that class, and as such, she needed to participate by reading a book. Mrs. Brown gave her the power to become an independent asker by helping her ask a friend for help. The power to become an independent learner is also a way to affirm identity as a language learner. I observed Victoria asking for help from another girl, on a different day when students were about to read a book. Mrs. Brown approaches all of her students as "special" and with the belief that each one has something special to give to the classroom community. This means that she tries to get to know each child and find out what they enjoy doing and what special talents or knowledge they have to share with the class. She knew that Victoria enjoyed reading and she was encouraging her to do that. On the other hand, Victoria was not only feeling satisfied to do that reading but she was having the chance to know about that piece of American culture through the reading of "Trick or Treat".

Vygotsky (1978) saw learning as the construction of knowledge through socialization. He introduced the term "mediation"which is a third element in an optimal teaching-learning context. In the above context, Mrs. Brown played the role of mediator by "supporting the learning but neither causing it to happen in any direct sense nor controlling the learning" (Goodman, 2003, p. 319). Vygotsky (1978) also introduced the notion of Zone of Proximal Development (ZPD) that describes "the distance between the actual developmental level [of the learner]..., determined by independent problem solving and the level of potential development, ... determined through problem solving under adult guidance" (Vygotsky, 1978, p. 86). Underlying this notion, there is an implicit understanding that social interaction, collaborative learning and participation are outstanding fundamentals in the learning process.

The following example is an excerpt from a home interaction in which Victoria described one of her class activities. In this example, she described when she was encouraged by Mrs. Brown to tell about her family and allowed her to use some "Spanish" to accomplish her task.

\section{Sample 3: Describing the family}

During the first week of class, Victoria was told to bring a picture and personal belongings to class. Children, as member of a new community, had to share personal information about 
them. Victoria's comments on this activity were "...todos, todos compartíamos las fotos, y enseñábamos, y este... todos enseñábamos la foto, donde era la foto, y las personas que aparecían en la foto y decíamos de donde éramos. ... Miss Brown me ayudó. Yo dije algunas cosas en español pero también sabía decir: sister, mom and dad." (... everybody, everybody had to share our photographs, and we showed, and uuhm, everybody showed the photo, where it was taken, and the people in the photo and we said where we were from... Mrs. Brown helped me. I said some words in Spanish but I also knew how to say: sister, mom and dad). Home interaction audio-taped in August 22nd

Victoria succeeded in this activity since she knew Mrs. Brown could understand some Spanish and she was allowed to use her native language to express her feelings. Mrs. Brown was there to scaffold her oral production and make Victoria feel fine about what she knew. Victoria felt satisfied and proud since she could use the few English words she was learning everyday for real purposes such as "mom", "sister" and "dad" within the phrases "esta es mi mother" (this is my 'mother'), "esta es mi sister" (this is my 'sister'). Goodman (1989) and Freeman and Freeman (1992) assert that learning a language is easy when it is used in authentic contexts with social function. Schwarzer (2007) also encourages to the need of teachers to foster minority students' use of their native languages in classrooms to help them develop their literacy skills.

Victoria told me that Mrs. Brown had been very helpful and allowed her speak Spanish when she did not know how to say something in English. Together, they tried to figure out what the Spanish words meant by using a bilingual dictionary. According to Schwarzer (2001) fostering the student's home language in class is a good way to empower them. Mrs. Brown's attitude to understand Victoria's cultural identity helped her feel proud of her Spanish identity and also feel proud of the English words she was learning which helped her accomplish the task. Contrary to many reports of discriminatory practices towards bilingual children (Cummins, 1996), Victoria was creating strong and positive feelings to her identity as a Spanish speaker and as a potential biliterate student.

\section{Reflecting on learning}

Victoria's reflections about her own English learning process are really interesting. Before starting her class she was anxious and nervous due to her language barrier, but gradually she started to feel confident of her progress as she could interact and participate in the different activities using the few English words she was learning every day. Every day I asked Victoria about her activities at school and sometimes asked her to write about what she experienced in class. The text in Figure 1 was written by her at the end of her first week of classes: 
doi: http://dx.doi.org/10.15359/ree.21-3.1

URL: http://www.una.ac.cr/educare

CORREO: educare@una.cr

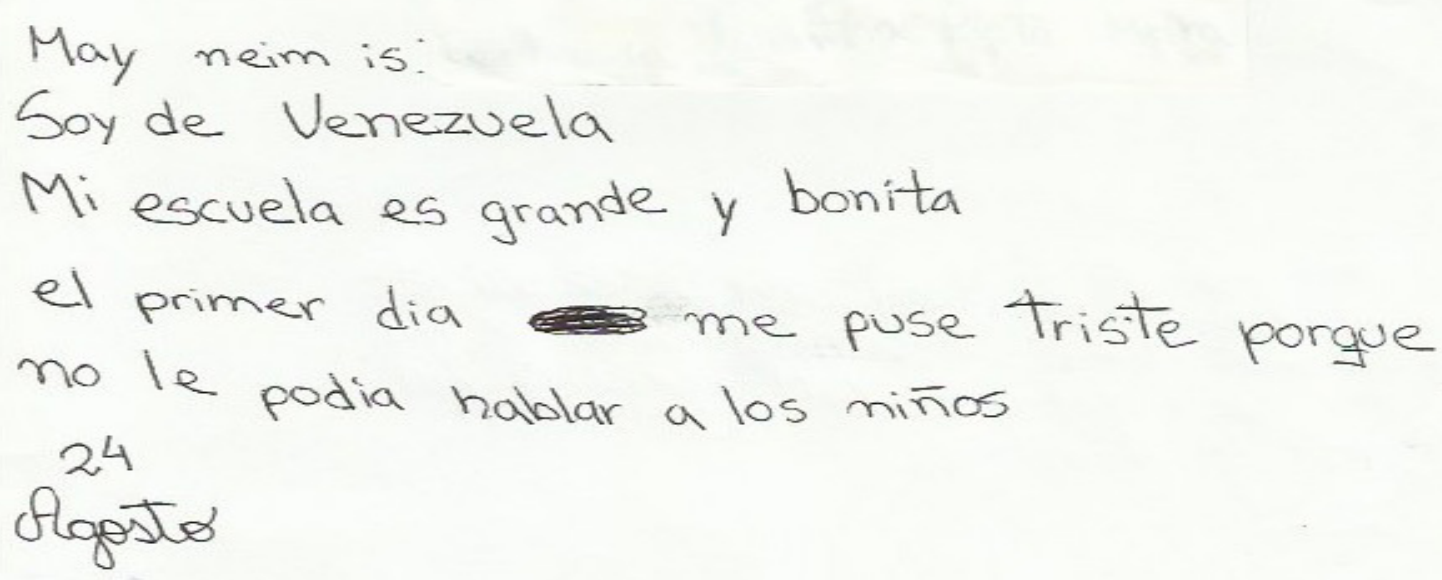

Figure 1: Victoria's written sample from August, 24th. Her text says: "My name is: I am from Venezuela. My school is big and beautiful. The first day I was sad because I wasn't able to talk to any children. August, 24th".

In that text, Victoria's intention was to describe her school and what she had experienced during the first day of classes. Her intent to produce English can be appreciated in the first sentence: May neim is (My name is), since in Spanish it is "Mi nombre es". As Victoria is fluent in Spanish and knows the Spanish sound system well, she used some of the Spanish written system to reproduce what she heard in English. The word "May" and "Neim" reflect the way a Spanish speaker would interpret and write them when they hear the English sounds "My" and "name". Unlike the English vowels, the Spanish vowels (a-e-i-o-u) have only one pronunciation scale, so they are always pronounced such as the sounds in the following English words: / apple/, /pet/, tipp/, /awesome/, and /putt/. Goodman (1989, 2003) proposes that individual personal construction of literacy knowledge is called invention. "Invention allows children to experiment and discover the ways in which written language is a tool for communication ... The social conventions of language keep these inventive forces in check and establish mutually comprehensible symbol systems in order for people to share meaning" (Whitmore, Martens, Goodman \& Owocki, 2004, p. 294). Victoria shifted from personal "invention" to a more social "convention" in her writings. While reflecting at home about the sound project discussed before, Victoria wrote the text shown in Figure 2. 


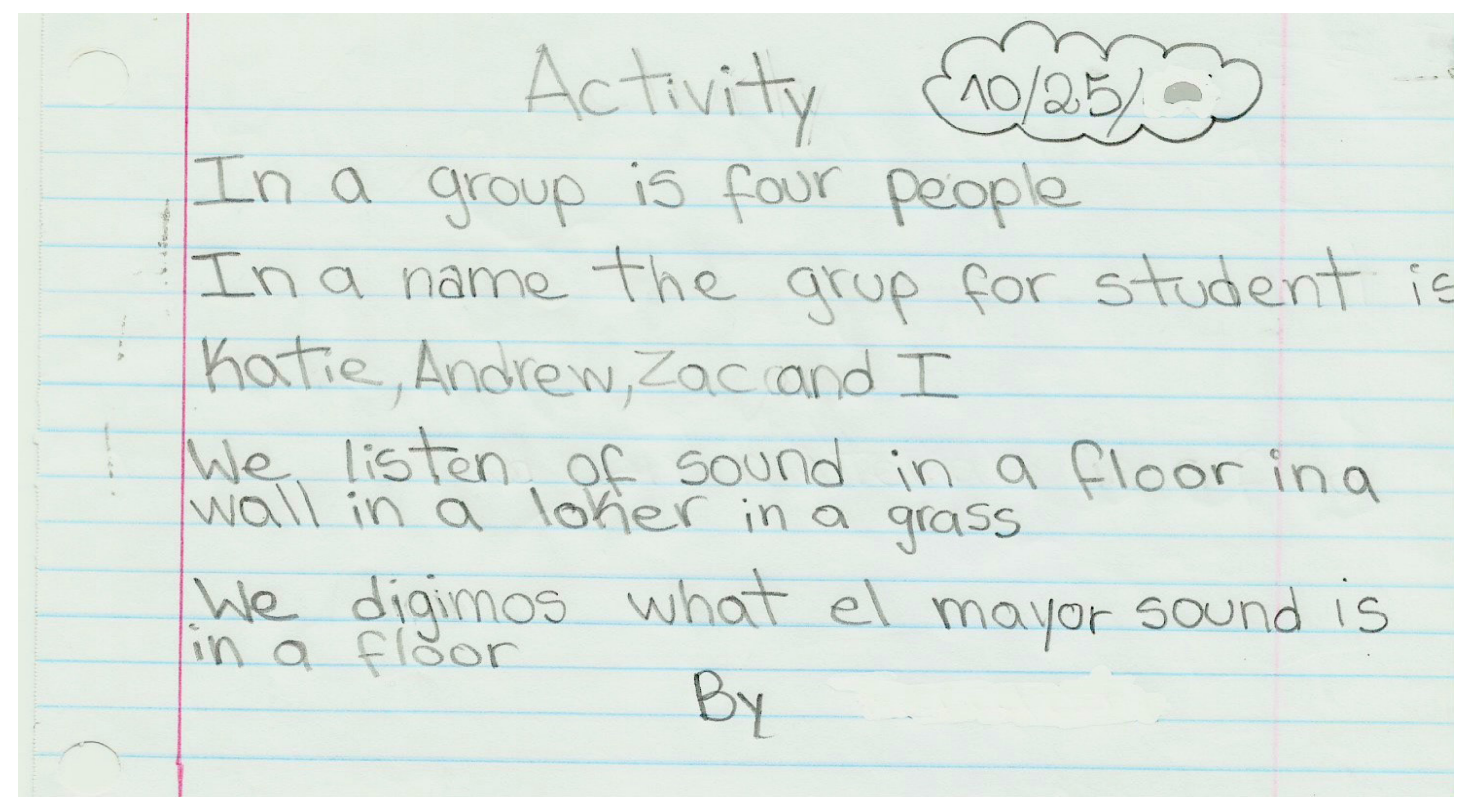

Figure 2: Victoria's written sample from October, 25th.

In that writing, we see Victoria's attempt to write in English and her ability to code switch to Spanish when she needed to express something she did not know yet in English. This written artifact reflects Victoria's process to shape her personal written system to the needs of the classroom, since it is almost entirely in English, and how she was learning to organize her written discourse to describe the group activity. She first presented the title "Activity" then she described the number of people in the group, their names, the task and the conclusion. We can interpret her writing as: Activity: In the group there are four people. The students' names in the group are: Katie, Andrew, Zack, and I. We heard the sound through the floor, the wall, and the lockers and through the grass. We concluded that the major sound was heard through the floor. Through these samples, we can see Victoria was developing a personal language system to satisfy her social goals as well using her Spanish background to understand and acquire literacy in English. In this respect, Cummins (1996) says that culturally diverse students usually develop a deeper conceptual and linguistic proficiency to form a "common underlying proficiency" which helps them transfer cognitive or literacy skills from their native language to understand literacy skills in their $L 2$. The text in Figure 3 was written during the sixth month of schooling in lowa City. In that text, Victoria feels more comfortable, her written discourse is a bit longer and it is written entirely in English. Besides, she expresses her likes and reflects about her feelings for her teacher and friends. 
doi: http://dx.doi.org/10.15359/ree.21-3.1

URL: http://www.una.ac.cr/educare

CORREO: educare@una.cr

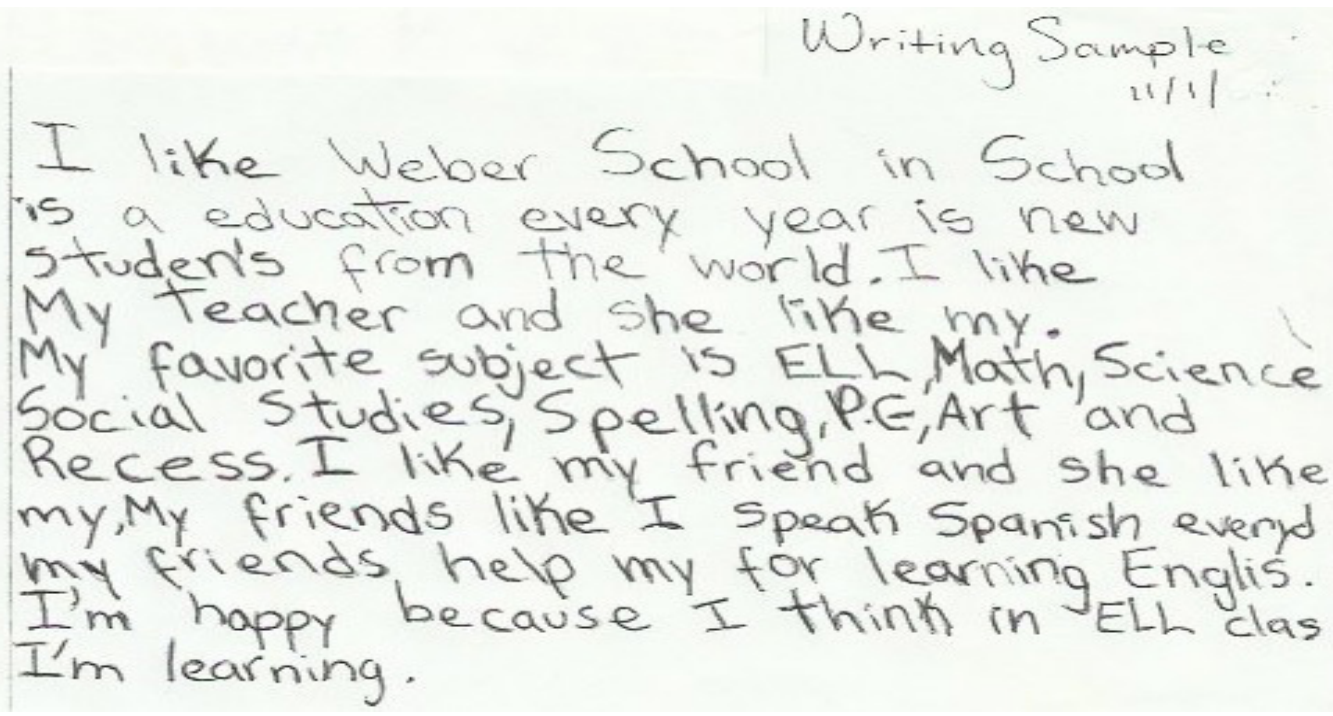

Figure 3: Victoria's written sample from January, 11 th.

\section{Discussion}

There are many factors that converge in Victoria' rich linguistic repertoire, since it obeys to a vast of variables which play fundamental roles in a second language learning process such as age, gender, social status; however, in this case study special attention will be paid to the kind of language she has been exposed to as a newcomer, the kind of classroom activities her teacher planned, the degree of her participation in those activities, the kinds of language-related games she engaged with peers, her family support to learn the new language and her attitude as a learner, among others. In order to systematically refer to my research questions, I will discuss each one of them separately, although we need to understand that Victoria's progress in English cannot be seen in isolation. Each one of these questions contributes to understand the others.

a) The first question asks: What kinds of activities did Victoria experience which made her move towards participation and become a legitimate member of her new community of practice?

Most of the activities I observed in Victoria's class were based on a strong community of learners, in which children could think, reflect, give opinions, ask for confirmation and make contributions to the whole process of knowledge construction; that is to say, children had the opportunity to learn by participating. These activities could easily be ranged in Cummins's (1996) quadrant B, since they allowed Victoria to engage in cognitively demanding and context-embedded interactions. Cummins (1996) suggests that "language and content will be acquired most successfully when students are challenged cognitively and provided with full of context" (p.60) such as the sound project group 
in which she had to make sense of the complex activity by the rich context that her peers were providing to construct knowledge not only in language but on physics of sounds. According to Cummins (1996), there are certain instructional approaches and techniques, which fall into the category of quadrant $B$, which is the most desired scenario for second language learners. Those activities should encourage the collaborative work, and provide cognitively demanding input with appropriate contextual support as the activities I observed in Victoria's classroom.

Victoria was not only learning a language but learning content through her participation and use of language. Halliday (1977) says"a child, in the act of learning language, is also learning the culture through language" (p. 66). Members in Mrs. Brown's class were learning to write by writing, learning to read by reading and learning oral skills by speaking. According to Halliday (1977) and Goodman (1989), learning takes place when students are engaged in real, meaningful and social interactions. Victoria had the choice of learning English since the very first day, by participating in different activities such as listening, asking, interacting, observing and reading. She played different roles in the different activities I observed and her degree of participation went from almost none to very frequent. By participating, getting familiar with the rules, habits and activities of the new community and interacting with old timers, Victoria moved from the peripherality towards a full participation as a legitimate member of such a community (Lave \& Wenger, 1991). Victoria seemed to participate and enjoy more the activities in which she had opportunities to ask questions and try her little English such as the family description activity. Her learning of English started to improve as she felt confident in speaking what she knew and had the chance to interact with her peers and participate in the activities. The kind of activities that encouraged Victoria to become a legitimate member of that new community considered three important constituents: they were social, active and meaningful.

b) The second research question deals with Victoria's identity: How is she portrayed as a legitimate participant in the new community?

Since the very beginning Victoria was accepted as one more member in that community of practice. She participated in all the activities Mrs. Brown planned and was included in the everyday responsibilities. As Mrs. Brown said, she worked hard to make everyone understand that newcomers have a lot of potential and a lot of knowledge to share. Victoria was seen by her peers as someone special who knew a different language which was "awesome" and someone who had experienced a different schooling system. From the onset, she started to make sense of the community she was welcome to participate as a newcomer, performing several roles in that community such as the community meetings, field trips, and responsibilities children must assume in the classroom community, such as the daily care a couple of children were required to give the new pet or her responsibility as an "old-timer" to help their "buddies", the more little ones from Team 1, during the recess time. Fernanda's learning began immediately from her first day as she engaged with others in a community that invited her to participate 
doi: http://dx.doi.org/10.15359/ree.21-3.1

URL: http://www.una.ac.cr/educare

CORREO: educare@una.cr

as a genuine member and empowered her as a language learner. She was transforming not only her behavior to do things but her identity as a learner, as a language user, as a friend, as a member of that particular group, and as a contributor toward the overall goal of the Team 3. This empowerment and affirmation of identity was possible due to Mrs. Brown and Victoria's peers established respect and trust among them. In her class, Victoria and peers were empowered to value and respect the others' differences.

This affirmation of identity was possible through "collaborative relations of power" (Cummins, 1996).

c) The third question refers to Mrs. Brown's mediation in her learning process: How did Mrs. Brown's mediation help Victoria reaffirm her identity as a language learner?

Mrs. Brown's help was crucial for Victoria's language development. Her own experience as a culturally diverse student helped her understand Victoria's diverse background. Her understanding and willingness to encourage her to move forward was evident in some of the activities described above such as the "collaborative reading" and the "family description". She helped Victoria move from the periphery to a more frequent participation instead of keeping her from participating such as those cases reported in Toohey (1998) and Norton (2001). Victoria had the chance to fully perform all those activities and to learn English to succeed in doing them. Mrs. Brown gave her the chance to feel she was learning by giving her oral feed-back such as "good" or "great" and also, she encouraged Victoria to take risks by asking questions and to use her native language to express her feelings (Goodman,1989; Freeman and Freeman, 1992; Schwarzer, 2007).

Mrs. Brown's attitude to understand Victoria's cultural identity helped her feel proud of her Latino identity and also feel proud of the English words she was learning which helped her accomplish the task. Victoria was invited to participate in that new community which implies a process of adaptation not only from her to the new community, but Mrs. Brown to Victoria's needs and ways to learn.

\section{Conclusion}

During the short period in which I traced Victoria's learning of English, I saw her learning English and her desire to actively participate in all the activities. She felt motivated to learn when she was engaged in activities which allowed her participate in social interactions which, in turn, lead her to the natural acquisition of her second language. She was more willing to participate and learn from the activities which were designed to learn through the constructions of meaning such as the Sound Project activity or the collaborative reading. Victoria showed her enthusiasm when participating and interacting in some class activities. The more she interacted 
with her teacher and friends, the better she performed in the use of the English language and at the same time, the better she performed, the more she interacted. Legitimate participation in school activities helped her improve her English language ability every day to the extent of being capable of code switching to help me understand English. The speed with which Victoria is learning English at school is mainly due to the solid community of practice she had the fortune to participate in and Mrs. Brown's mediation, among other factors.

This study suggests that students engage more actively in activities, which are designed to construct meaning through social participation. It is through social interaction that children learn a new language. Social interaction as stated by Vygotsky (1978) can be connected to other idea about the process of learning such as the relationship found in a "community of practice" when the newcomer interacts with other old-timers to become a full participant. From the periphery to full participation new members get involved in different processes where they interact and transact with others to learn the existing code of the community of practice, but also to contribute by participating. Social interaction entails learning and is fundamental for the process of becoming a new member in a community. In the same way, this notion of social interaction is clearly reflected in Cummins's (1996) "Collaborative relations of power", since this reciprocal relationship helps students and teachers affirm their own identities and respect others.

This study does not seek to stigmatize the Venezuelan educational system but to reflect on Victoria's experiences as a language learner during the first six months in a school in lowa City in order to understand her L2 proficiency. Neither does this study seek to fully describe Victoria's English learning process but to provide practical examples that may reflect the theoretical constructs of legitimate peripheral participation and collaborative relations of power as lenses to analyze learning. In addition, this research has given me alternative ways to understand Victoria's experience as a language learner, the complexity of a second language learning process and the fundamental and pivotal role teachers and parents need to perform to mediate in the students' learning to reaffirm their identities.

Some research and pedagogical implications also arise from this study. On one hand, although research by parents brings about discussions about the negative limitations that could obscure the results of the study, mainly due to the researcher's bias, these kind of studies also offer valuable and fascinating data which contribute to the understanding of the complex L2 learning process phenomenon. Awareness to avoid possible misinterpretations or misunderstandings in the analysis of the data to empower the validity of the study should be taken. On the other hand, Victoria's experience during her first six months at school represents an exemplary reflection of what we, as language teachers, should do in our classrooms if we really want to offer students real opportunities to learn the language and help them reaffirm their identity. We need to understand and be aware of our teaching contexts, whether it is ESL or EFL, so that we can adapt strategies to make them available and useful in each context. 
doi: http://dx.doi.org/10.15359/ree.21-3.1

URL: http://www.una.ac.cr/educare

CORREO: educare@una.cr

Victoria's experience was developed in a SL teaching/learning context, however, with careful attention, activities like those could be adapted and applied in FL teaching/learning contexts. As language teachers, we need to construct a strong community of practice in which everyone becomes a legitimate member who actively moves from the periphery to the full participation.

\section{References}

Back, M. (2011). Legitimate peripheral participation and language learning: Two Quichua learners in a transnational community. Language Learning, 61(4), 1039-1057. doi: https:// doi.org/10.1111/j.1467-9922.2011.00662.x

Bacon, S. M. (2002). Learning the rules: Language development and cultural adjustment during study abroad. Foreign Language Annals, 35(6), 637-646. doi: https://doi. org/10.1111/j.1944-9720.2002.tb01902.x

Bayley, R., \& Schecter, S. R. (2005). Family decision about schooling and Spanish maintenance: Mexicanos in California and Texas. In A. C. Zentella (Ed.), Building on strength. Language and literacy in latino families and communities (pp. 31-45). New York: Teachers College Press.

Bhimji, F. (2005). Language socialization with directives in two Mexican immigrant families in South Central Los Angeles. In A. C. Zentella (Ed.), Building on strength. Language and literacy in latino families and communities (pp. 60-76), New York: Teachers College Press.

Bissex, G. L. (1980). Gnys at wrk: A child learns to write and read. Cambridge, Mass: Harvard University Press.

Cazden, C. B. (2001). Classroom discourse. The language of teaching and learning. Portsmouth, $\mathrm{NH}$ : Heinemann.

Chiseri-Strater, E., \& Sunstein, B. S. (2006). What works? A practical guide for teacher research. Portsmoth, NH: Heinemann.

Cummins, J. (1996). Negotiating identities: Education for empowerment in a diverse society. Los Ángeles: California Association for Bilingual Education.

Ek, L. D. (2005). Staying on God's path. Socializing latino immigrant youth to a Christian Pentecostal identity in southern California. In A. C. Zentella (Ed.), Building on strength. Language and literacy in latino families and communities (pp. 77-92), New York: Teachers College Press.

Foucault, M. (1990). The history of sexuality: An introduction. New York, NY: Vintage Books.

Foucault, M. (1995). Discipline \& punish: The birth of the prison. New York, NY: Vintage Books. 
Freeman, Y. S., \&. Freeman, D. E. (1992). Whole language for second language learners. Portsmouth, $\mathrm{NH}:$ Heinemann.

Freeman, Y. S., \&. Freeman, D. (1998). ESL/EFL teaching. Principles for success. Portsmouth, NH: Heinemann.

Glesne, C. (2006). Becoming qualitative researchers. An introduction (3a ed.). NY: Pearson Education.

González-Howard, M., \& McNeill, K. L. (2016). Learning in a community of practice: Factors impacting English-learning students' engagement in scientific argumentation. Journal of Research in Science Teaching, 53(4), 527-553 . doi: https://doi.org/10.1002/tea.21310

González, N., Moll, L.C., \&, Amanti, C. (Eds.). (2005). Funds of knowlege. Theorizing practices in households, communities and classrooms. Mahwah, New Jersey: Lawrence Erlbaum Associates, Publishers.

Goodman, K. (1989). El Lenguaje Integral. Mérida: Editorial Venezolana.

Goodman, K. (2003). Language and learning: Toward a social-personal view. In A. Flurkey, \& J. Xu (Eds), On the revolution of reading. Portsmount, $\mathrm{NH}$ : Heinemenn.

Hakuta, K. (1976). A case study of a Japanese child learning English as a second language. Language Learning, 26(2), 321-351. doi: https://doi.org/10.1111/j.1467-1770.1976. tb00280.x

Hakuta, K. (1986). Mirror of language. The debate on bilingualism. New York: Basic Books.

Halliday, M. A. K. (1977). Learning how to mean. Explorations in the development of language. New York: Elsevier.

Han, H. (2009). Institutionalized inclusion: A case study on support for immigrants in English learning, TESOL Quarterly, 43(4), 643-668. doi: https://doi.org/10.1002/j.1545-7249.2009. tb00190.x

Lave, J., \& Wenger, E. (1991). Situated learning. Legitimate peripheral participation. New York: Cambridge University Press. doi: https://doi.org/10.1017/CBO9780511815355

Martens, P. (1996). I already know how to read:A child's view of literacy. Portsmouth, NH: Heinemann.

Merriam, S. (1998). Qualitative research and case study applications in education. San Francisco, Jossey-Bass Publishers.

Morita, N. (2004). Negotiating participation and identity in second language academic communities. Tesol Quarterly, 38(4), 573-603. doi: https://doi.org/10.2307/3588281 
doi: http://dx.doi.org/10.15359/ree.21-3.1

URL: http://www.una.ac.cr/educare

CORREO: educare@una.cr

Nordstrom, J. (2015). Flexible bilingualism through multimodal practices: Studying K-12 community languages online. International Journal of Bilingual Education and Bilingualism, 18(4), 395-408. doi: https://doi.org/10.1080/13670050.2014.909773

Norton, B. (2001). Non-participation, imagined communities and the language classroom. In M. P. Been (Ed.), Learner contributions to language learning: New directions in research (pp. 159-171). London: Routledge.

Schwarzer, D. (2001). Noa's ark. One child's voyage into multiliteracy. Portsmouth, NH: Heinemann.

Schwarzer, D. (2007). Monolingual teachers fostering students' native literacies. In Y. Goodman \& P. Martens (Eds.), Critical issues in early literacy (pp. 111-122). Research and pedagogy. New Jersey: Lawrence Erlbaum Associates.

Smith, F. (1998). The Book of learning and forgetting. New York, NY: Teacher College Press.

Toohey, K. (1998). "Breaking them up, taking them away": ESL students in grade 1. TESOL Quarterly, 32(1), 61-84. doi: https://doi.org/10.2307/3587902

Vygotsky, L. (1978). Mind in society. The development of higher psychololgical processes. Cambridge, MA: Harvard University Press.

Wei, Y., \& Zhou, Y. (2003). Language minority parents' involvement in their child's english education: A case study of a young ELL student. Paper presented at the $37^{\text {th }}$ Annual Meeting of Teachers of English to Speakers of other Languages, Baltimore. Recuperado de http://files. eric.ed.gov/fulltext/ED476593.pdf

Wenger, E. (1998). Communities of practice: Learning, meaning and identity. Cambridge, UK: Cambridge University Press. doi: https://doi.org/10.1017/CBO9780511803932

White, L. (2003). Second language acquisition and universal grammar. New York: Cambridge University Press. doi: https://doi.org/10.1017/CBO9780511815065

Whitmore, K. F., Martens, P., Goodman, Y. M., \& Owocki, G. (2004). Critical lessons from the transactional perspective on early literacy research. Journal of Early Childhood Literacy, 4(43), 291-325. doi: https://doi.org/10.1177/1468798404047291

Zentella, A. C. (2005). Premises, promises and pitfalls of language socialization research in latino families and communities. In A. C. Zentella (Ed.), Building on strength. Language and literacy in Latino families and communities (pp. 13-30). New York: Teachers College Press. 